UDC 537.533:539.9

\author{
I.Yu. Bakeev, A.A. Zenin, A.V. Tyun'kov, A.S. Klimov
}

\title{
Composition of the gas atmosphere during the electron beam interaction with the alumina powder in the forevacuum pressure range
}

\begin{abstract}
The results of the investigation of the composition of the gas atmosphere during the electron beam interaction with alumina powder in the forevacuum pressure range are presented. It is shown that during the beam interactions with the powder, there is an intensive outgassing from the particle surface. These gases are water vapor, helium, carbon dioxide, carbon monoxide or nitrogen. Thus, when the electron beam irradiation of alumina powder is performed, the spread of powder particles is carried out by intensive desorption of molecules adsorbed on the surfaces during location in the atmosphere.
\end{abstract}

Keywords: alumina, electron beam, forevacuum pressure range, outgassing. doi: $10.21293 / 1818-0442-2016-19-4-13-16$

Nowadays special attention is given to the development of three-dimensional printing technology products using different materials [1], including ceramic [2], and their introduction into manufacturing. Despite of the variety of printing methods for ceramics (stereolithography (SLA) [3], laminated object manufacturing (LOM) [4], selective laser sintering (SLS) [5], fused deposition modeling (FDM) [6], three-dimentional printing (3DP) [7], etc.), all of them implement a same principle. This principle includes a layer-by-layer forming of a ceramic batch shape using binders and its subsequent post-processing in a high temperature furnace for binder removal and direct sintering of the powder particles. It should be noted that exist no articles devoted to using an electron-beam for a layer-by-layer forming of ceramic. One of the reasons complicating the usage of this technology for ceramic is powder spreading caused by the electron-beam action. The most probable cause of this phenomena is charging of particles [8].

This problem can be solved in two ways: 1) a special mechanism of charge compensation and 2) a forevacuum plasma source $[10,11]$ working in the pressure range from several to dozens of Pascals to generate the electron beam. In the latter case, the compensation of the charge on dielectric surfaces is performed by the ion flow from plasma produced by the electron beam propagation.

In the article are presented the investigations of the alumina powder electron-beam treatment by the forevacuum electron source, previously mentioned in [11, 12]. It is shown that despite the compensation of the negative charge by the ion flow from beam plasma, powder particle spread is still observed. Intensive outgassing from the particle surface is recognized as one of the main reasons of this phenomena.

The aim of this work was to investigate the composition of the gas atmosphere during the electron beam interaction with the alumina powder in the forevacuum pressure range.

\section{Techniques and methods}

The scheme of the experimental setup is shown in Fig. 1. The treatment of alumina powder by an electron beam is performed by two techniques.

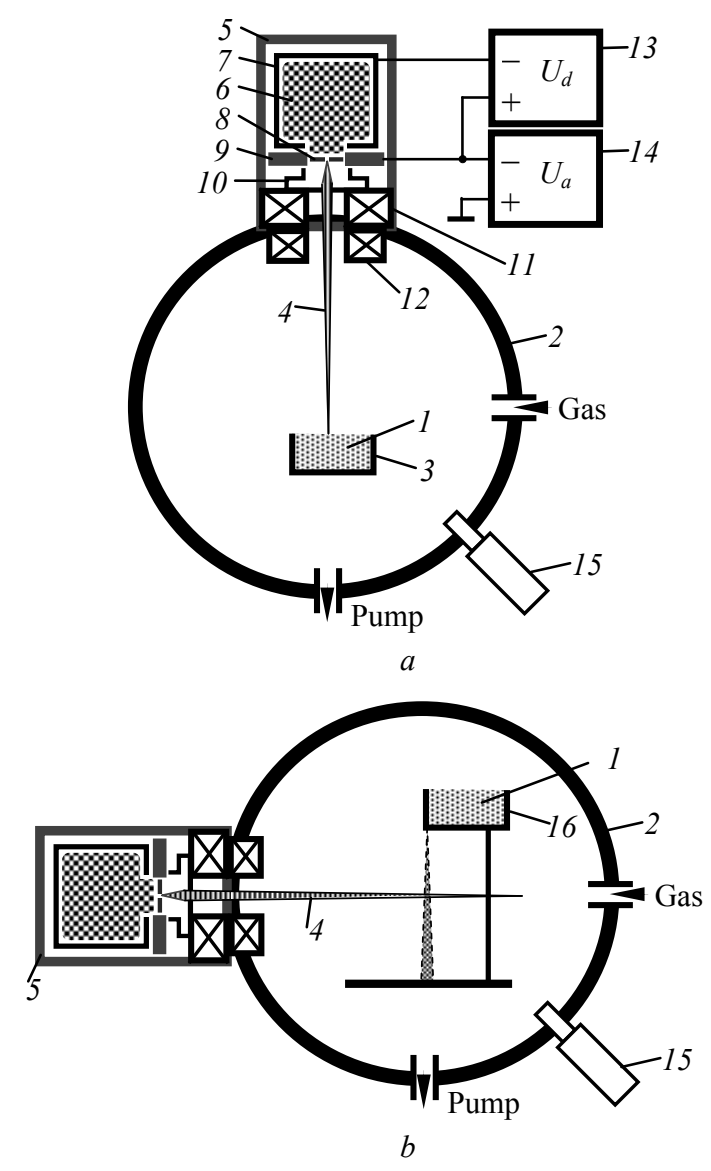

Fig. 1. Scheme of experimental setup: $a$ - electron-beam irradiation of powder in the crucible; $\sigma$ - electron-beam irradiation of falling powder; 1 - alumina powder; 2 - vacuum chamber; 3 - graphite crucible; 4 - electron beam; 5 - forevacuum electron source; 6 - emission plasma; 7 - hollow cathode; 8 - anode; 9 - perforate electrode; 10 - extractor (grounded electrode); 11 - magnetic focusing system; 12 - magnetic deflection system; 13 - discharge power supply; 14 - accelerating voltage power supply; 15 - container with the hole for powder falling

In the first technique, the alumina powder 1 in a graphite crucible 2 is placed in the vacuum chamber 3 and irradiated by an electron beam 4 generated by the forevacuum plasma electron source 5 [10]. The electron 
beam 4 , with diameter about $1 \mathrm{~mm}$, is formed by electron extraction from emission plasma 6 , produced by the glow discharge with a hollow cathode 7 , though the central hole (diameter $-0.75 \mathrm{~mm}$ ) in the perforated electrode 8 overlapping the emission aperture in the anode 9. The voltage $U_{a}$ applied between the anode 9 and the grounded extractor 10 performs the acceleration of the electrons to the required energies. After that, the electron beam is exposed to focusing by the magnetic coil 11 and scanning by the magnetic deflection system 12 into a square image on the powder surface.

The power of the discharge and the accelerating voltage is produced by the discharge power supply 13 and the accelerating voltage supply 14 respectively. The beam current is measured by deflection off to a detached current collector.

Pumping of the vacuum chamber is produced only by a forevacuum pump, and pressure $P$ in the vacuum chamber is controlled by feeding the working gas (air).

The composition of the gas atmosphere is defined using the industrial residual gas analyzer RGA 10015 (Stanford Research Systems). The sensor of the analyzer is pumped by the individual vacuum system comprising the membrane and turbomolecular pumps. To provide the necessary pressure drop between the vacuum chamber and the sensor, the diameter of the entry hole in the analyzer should not exceed $1 \mathrm{~mm}$.

The second technique have two differences: the alumina powder particles are falling through the hole in one edge in the container 16 (Fig. $1, b$ ); the irradiation of falling powder particles is performed by the horizontally oriented electron beam. In this case the diameter of the beam is $20 \mathrm{~mm}$.

\section{Experimental results}

In Fig. 2 are presented the mass spectra of the residual atmosphere (Fig. 2, $a$ ) and the gas atmosphere (Fig. 2,b,c) in the vacuum chamber during electronbeam treatment of alumina powder in the graphite crucible at different parameters of the electron beam.

It can be seen from these results that there is water vapor $(\mathrm{m} / \mathrm{z}=17$ и 18$)$ and molecules of residual gas (helium $\mathrm{m} / \mathrm{z}=2$, carbon dioxide $\mathrm{CO}_{2} \mathrm{~m} / \mathrm{z}=44$, nitrogen $\mathrm{N}_{2}$ or carbon monoxide $\mathrm{CO} m / z=28$ ) in a significant amount in the vacuum chamber before treatment of the powder (Fig. 2,a).

During irradiation with a low power density of the beam (Fig. 2, $b$ ) with pressure increasing to $P=3.5 \mathrm{~Pa}$, the following changes in the mass spectra take place: the peak height $m / z=17$ and 18 decreases that indicates gradual pumping of water vapor from the vacuum chamber; the concentration of $\mathrm{CO}$ or $\mathrm{N}_{2}$ trebles $(m / z=28)$; the rise of the peak $m / z=44\left(\mathrm{CO}_{2}\right)$ is observed; the peaks $m / z=32$ (which corresponds to the oxygen) and $m / z=14$ (atomic nitrogen) appear. During irradiation with the power density $P_{S}=100 \mathrm{~W} / \mathrm{cm}^{2}$ (melting of alumina particles is observed, $P=5 \mathrm{~Pa}$ ), the working chamber is filled mainly with water vapor, helium and carbon monoxide (Fig. 2, c). It should be noted that the concentration of gases increases almost 8 times when compared to the initial situation (Fig. 2, a), and concentration of water vapor increases by $20 \%$. The latter fact, together with the other results, may indicate that the pressure rise in the vacuum chamber during heating alumina powder by the electron beam comes from intensive outgassing of gas and water molecules adsorbed on the powder particle surfaces when the powder was located in atmosphere.
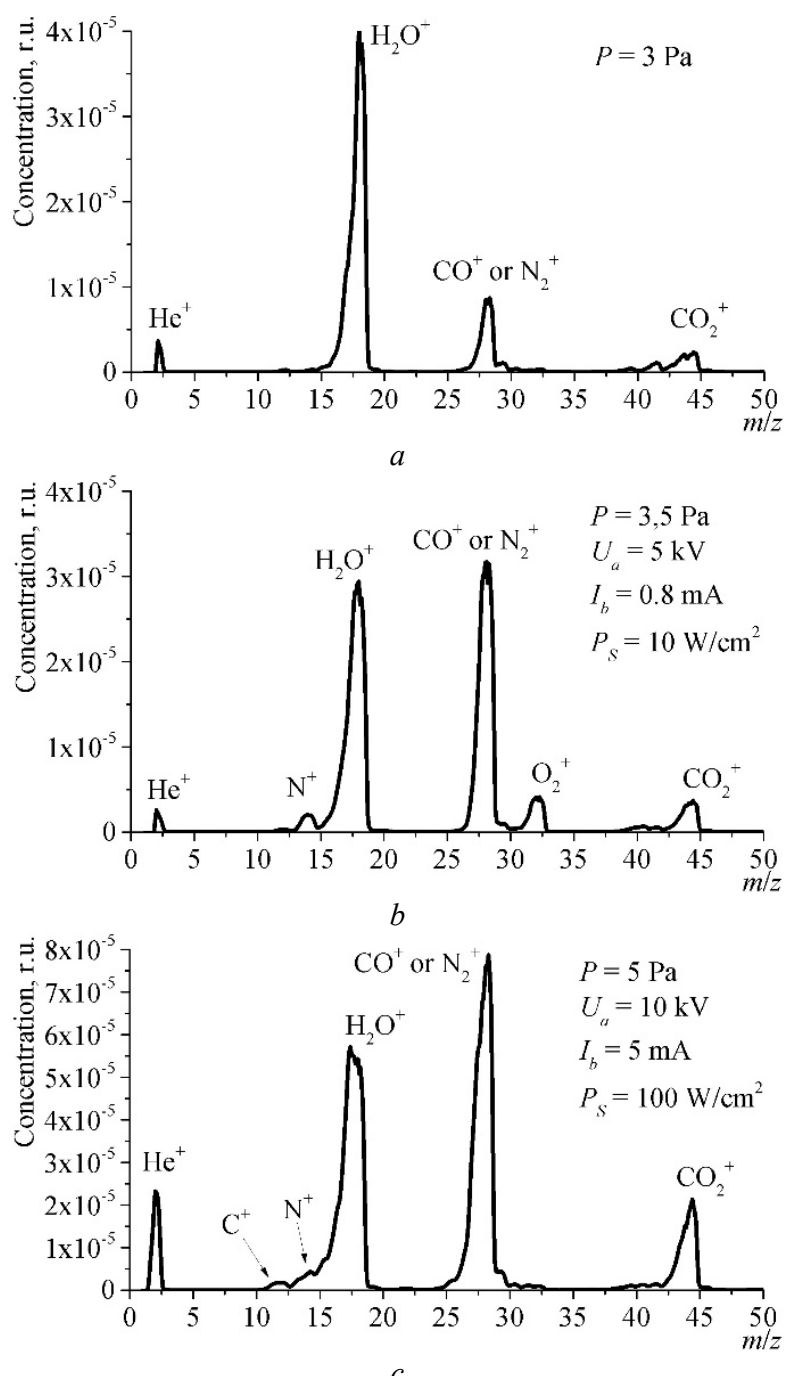

Fig. 2. Composition of residual atmosphere before treatment (a) and the gas atmosphere during electron-beam treatment of alumina powder in the graphite crucible at different parameters of electron beam $(b, c)$

The increasing pressure in the vacuum chamber may also be connected with heating the graphite crucible, in which the powder is located. In this case the outgassing is performed from the crucible surface: its can be molecules of gases, water; but also can take place burning of residual organic compounds. Thus, the appearance of peak $\mathrm{m} / \mathrm{z}=12$ corresponding to carbon in Fig. 2, $c$ confirms the influence of the crucible on the results obtained by the first technique.

To eliminate the influence of the crucible on the composition of the gas atmosphere, the experiment was conducted using the second technique where the irradiation of the falling powder particles through the hole in 
the container (Fig. 1,b) is performed by the horizontal oriented electron beam. The dynamic of changes in the gas atmosphere during the irradiation with beam parameters $U_{a}=10 \mathrm{kV}, I_{b}=30 \mathrm{~mA}, P_{s}=95 \mathrm{~W} / \mathrm{cm}^{2}$ is presented in Fig. 3.

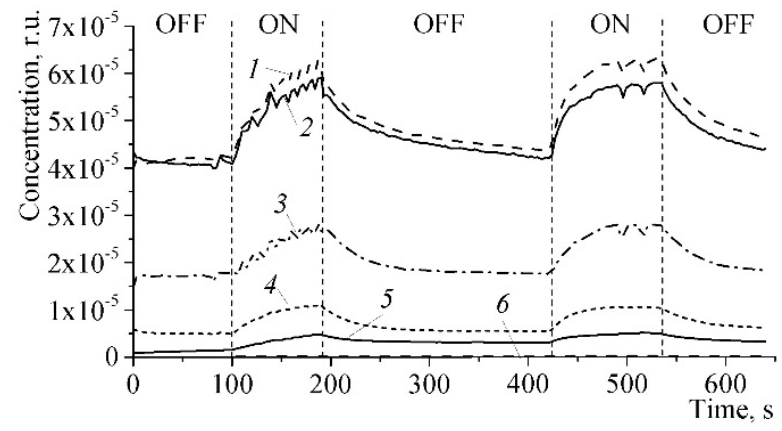

Fig. 3. Dynamic of changes in the gas atmosphere during irradiation of falling powder particles by electron beam

(area $\mathrm{ON}): 1-\mathrm{m} / \mathrm{z}=17\left(\mathrm{H}_{2} \mathrm{O}\right) ; 2-m / z=18\left(\mathrm{H}_{2} \mathrm{O}\right)$;

$3-m / z=28\left(\mathrm{~N}_{2}\right.$ или $\left.\mathrm{CO}\right) ; 4-m / z=44\left(\mathrm{CO}_{2}\right)$;

$5-m / z=14(\mathrm{~N}) ; 6-m / z=32\left(\mathrm{O}_{2}\right)$

When the beam is turned on before the irradiation moment, the pressure in the vacuum chamber reaches 8 $\mathrm{Pa}$ (Fig. 3, area OFF, time $t=0-100 \mathrm{~s}$ ). As can be seen from the dynamics in Fig. 3, when the spilling mechanism of powder is turned on and the powder particles cross the beam, concentration of water vapor and the investigated gases begin to increase (area ON, $t=100$ $185 \mathrm{~s})$. When the spilling mechanism is turned off $(t=185 \mathrm{~s})$, the pressure in the vacuum chamber equals to $12 \mathrm{~Pa}$ and begins to decrease (area OFF, $\mathrm{t}=t=185-$ $420 \mathrm{~s}$ ). Then, the concentration of water vapor and gases down to the initial level $(t=420 \mathrm{c})$. When the spilling mechanism is turned on and turned off again, the described phenomena is observed as well (area ON, $t=420-535 \mathrm{~s}$; area OFF $t>535 \mathrm{~s}$ ).

Fig. 4. presents mass spectra obtained during electron-beam irradiation of the falling particles, when the pressure is increased to the maximum in the experiment,

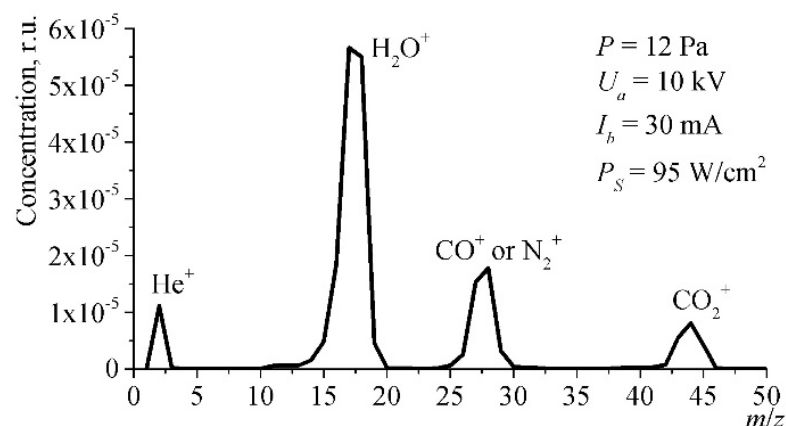

Fig. 4. Composition of gas atmosphere during electron-beam treatment of falling powder particles

This mass spectra is qualitatively different from the mass spectra, obtained when irradiation of the powder was performed in the crucible, by the absence of peaks of carbon $\mathrm{C}(\mathrm{m} / \mathrm{z}=12)$ and atomic nitrogen $\mathrm{N}(\mathrm{m} / \mathrm{z}=14)$. The concentration of water vapor, helium, carbon diox- ide, carbon monoxide and nitrogen significantly prevails over the content of other gases in both techniques.

Thus, the results obtained when investigating the gas atmosphere composition during the electron beam interaction with the falling alumina powder-also confirm that the increasing pressure in the vacuum chamber during the treatment is caused by outgassing of gas and water vapor adsorbed during location in the atmosphere from the surface of the particles.

\section{Conclusion}

The composition of the gas atmosphere during the electron beam interaction with the alumina powder in the forevacuum pressure range is investigated by two techniques: irradiation of the powder in a graphite crucible and irradiation of falling powder particles. The results of using both techniques indicate that when interaction of the electron beam with powder particles is performed, the intensive outgassing of water vapor, helium, carbon dioxide, carbon monoxide, nitrogen from the particle surface is produced. This confirms the assumption that the intensive outgassing is the reason why particles spread during electron-beam irradiation. 00871 .

This work is supported by RFBR grant No. 15-08-

\section{References}

1. Chua C.K., Leong K.F., Liu Z.H. Rapid Tooling in Manufacturing // Handbook of Manufacturing Engineering and Technology, 2015. - PP. 2525-2549.

2. Tay B.Y., Evans J.R.G., Edirisinghe M.J. Solid freeform fabrication of ceramics // International Materials Reviews. -2003 . - Vol. 48. - PP. 341-370.

3. Chartier T., Chaput C., Doreau F., Loiseau M. Stereolithography of structural complex ceramic parts // Journal of materials science. - 2002. - Vol. 37. - PP. 3141-3147.

4. Zhang Y., He X., Du S., Zhang J. Al2O3 Ceramics Preparation by LOM (Laminated Object Manufacturing) / Int. J. Adv. Manuf. Technol. - 2001. - Vol. 17. - PP. 531-534.

5. Liu F.H., Liao Y.S. Fabrication of inner complex ceramic parts by selective laser gelling // Journal of the European Ceramic Society. - 2010. - Vol. 30. - PP. 3283-3289.

6. Bellini A., Shor L., Guceri S.I. New developments in fused deposition modeling of ceramics // Rapid Prototyping Journal. - 2005. - Vol. 11, No. 4. - PP. 214-220.

7. Lewis J.A., Smay J.E., Stuecker J., Cesarano J. Direct Ink Writing of Three-Dimensional Ceramic Structures // J. Am. Ceram. Soc. - 2006. - Vol. 89, No. 12. - PP. 3599-3609.

8. Sigl M., Lutzmann S., Zäh M.F. Transient Physical Effects in Electron Beam Sintering // Solid Freeform Fabrication Symposium Proceedings 17, Austin, Texas/USA. - 2006. PP. 397-405.

9. Burdovitsin V.A., Klimov A.S., Oks E.M. On the possibility of electron-beam processing of dielectrics using a forevacuum plasma electron source // Technical Physics Letters. - 2009. - Vol. 35, No. 6. - PP. 511-513.

10. Kazakov A.V., Klimov A.S., Zenin A.A. Electronnoluchevoy sintez dioksidtsirkonievoy keramiki [Electron-beam synthesis of zirconia ceramics] // Doklady Tomskogo gosudarstvennogo universiteta sistem upravleniya i radioelektroniki. - 2012. - No. 2(26), Part 2. - PP. 186-189.

11. Bakeev I.Yu., Zenin A.A., Klimov A.S. Osobennosti obrabotki dielektricheskikh poroshkov elektronnym luchom v forvakuume [Features of treatment of dielectric powders by an electron beam in the forevacuum pressure range] // Perspek- 
tivy razvitiya fundamentalnykh nauk: sbornik trudov XIII Mezhdunarodnoy konferentsii studentov, aspirantov I molodykh uchenykh [Prospects of Fundamental Sciences Development: Proc. XIII International Conference of Students and Young Scientists]. - Tomsk: Natsionalnyy Issledovatelskiy Tomskiy politekhnicheskiy universitet. - 2016. - Vol. 7. PP. 24-26.

12. Bakeev I.Yu., Zenin A.A. O vozmozhnosti obrabotki dielektricheskikh poroshkov electronnym puchkom $\mathrm{v}$ forvakuume primenitelno $\mathrm{k}$ tekhnologii 3d-prototipirovaniya [About the possibility of treatment of dielectric powders by an electron beam in conformity with rapid prototyping] // Nauchnaya sessiya TUSUR-2016: meterialy Mezhdunarodnoy nauchno-tekhnicheskoy konferentsii studentov, aspirantov i molodykh uchenykh [Scientific session of TUSUR-2016: proc. International Scientific-technique Conference of Students, Postgraduate Students and Young Scientists]. - Tomsk: V-Spektr, 2015. - Part. 2. - PP. 106-108.

\section{Bakeev Ilya Yur'evich}

TUSUR, department of physics, junior research scientist Phone: +7-953-923-17-26

E-mail: bakeeviyu@mail.ru

\section{Zenin Aleksey Aleksandrovich}

TUSUR, department of physics, senior research scientist, $\mathrm{PhD}$ Phone: +7-952-807-62-02

E-mail: zenin1988@gmail.com

\section{Tyun'kov Andrey Vladimirovich}

TUSUR, department of physics, senior research scientist, PhD Phone: +7-952-884-35-11

E-mail: andrew71@sibmail.com

\section{Klimov Aleksandr Sergeevich}

TUSUR, department of physics, senior research scientist, $\mathrm{PhD}$ Phone: +7-952-884-35-11

E-mail:klimov@main.tusur.ru

Бакеев И.Ю., Зенин А.А., Тюньков А.В., Климов А.С. Состав газовой атмосферы при взаимодействии электронного пучка с порошком оксида алюминия в форвакуумной области давлений

Представлены результаты исследований состава газовой атмосферы при взаимодействии электронного пучка с порошком оксида алюминия в форвакуумной области давлений. Показано, что в момент взаимодействия пучка с порошком происходит интенсивное газовыделение с поверхности частиц паров воды, гелия, диоксида углерода, монооксида углерода или азота. Таким образом, при облучении порошка оксида алюминия электронным лучом в форвакуумной области давлений разлет частиц обусловлен интенсивной десорбцией молекул, адсорбированных на их поверхности.

Ключевые слова: оксид алюминия, электронный пучок, форвакуумная область давлений, газовыделение. 